\title{
Water ingestion dynamics in patients with achalasia: influence of sex and age
}

\author{
Roberto Oliveira DANTAS, Rachel Aguiar CASSIANI, Carla Manfredi SANTOS and \\ Leda Maria Tavares ALVES
}

Received 21/2/2018 Accepted 25/4/2018

\begin{abstract}
Background - Achalasia is a disease that affects esophageal bolus transit due to the absence of esophageal peristaltic contractions and impaired or absent relaxation of the lower esophageal sphincter. Objective - The objective of this investigation was: a) to evaluate the dynamics of water ingestion in patients with achalasia, idiopathic or caused by Chagas' disease; b) to evaluate the influence of sex and age on water ingestion dynamics. Methods - The investigation was conducted with 79 patients with achalasia (27 idiopathic and 52 Chagas' disease) and 91 healthy volunteers, all evaluated by the water-drinking test. The individuals drank, in triplicate, $50 \mathrm{~mL}$ of water without interruption. The time and the number of swallows for this task were counted. We also measured: (a) inter-swallow interval - the time to complete the task, divided by the number of swallows during the task; (b) swallowing rate - volume drunk divided by the time; (c) volume per swallow - volume drunk divided by the number of swallows. Results - Patients with achalasia took longer to ingest all the volume (mean 12.2 seconds) than healthy controls (mean 5.4 seconds), had greater number of swallows, longer interval between swallows, lower swallowing rate $(5.2 \mathrm{~mL} / \mathrm{s}$ vs $10.9 \mathrm{~mL} / \mathrm{s}$ in controls) and lower volume per swallow (9.1 mL vs 14.4 $\mathrm{mL}$ in controls, $P<0.01$ ). Among healthy volunteers, women had a shorter interval between swallows and lower volume per swallow compared with men, and in the achalasia group, women had a longer interval between swallows and lower ingestion rate. No difference in the drinking test results was found between younger and older subjects in achalasia or control group. Also, no differences were observed between patients with Chagas' disease and those with idiopathic achalasia, or between patients with increased and normal esophageal diameter. Conclusion - Patients with achalasia have difficulty in ingesting water, taking a longer time to complete the task, which is influenced by sex but not by age or severity of the disease.

HEADINGS - Deglutition disorders. Esophageal achalasia. Chagas' disease. Esophagus. Deglutition. Esophageal diseases. Esophagogastric junction.
\end{abstract}

\section{INTRODUCTION}

Dysphagia for liquid and solid foods and regurgitation are the most frequent symptoms of achalasia ${ }^{(1-7)}$, an esophageal motility disorder caused by impairment or loss of the neurons of the esophageal myenteric plexus ${ }^{(1-7)}$, with decreased or absent lower esophageal sphincter (LES) relaxation and loss of peristaltic contractions in the esophageal body ${ }^{(1,4,5)}$. Achalasia may be idiopathic $^{(1,2,4)}$ or associated with a known disease ${ }^{(8)}$, such as Chagas' disease, a tropical parasitic disease caused by the flagellate protozoan Trypanosoma cruzi $i^{(6,7)}$.

Patients with achalasia caused by Chagas' disease take longer to drink a volume of water, with slower swallowing rate and lower volume in each swallow than controls subjects ${ }^{(9)}$. Previous investigations showed, using the water-drinking test, that healthy women, compared with healthy men, have lower swallowing capacity and volume per swallow ${ }^{(10,11)}$. In addition, aging process causes a decline in the volume per swallow and in swallowing capacity ${ }^{(10)}$. However, the effect of age and sex have not been reported in achalasia. Our hypothesis was that sex and age have influence on the dynamics of water ingestion in patients with achalasia.

Our aim in this investigation was to: a) evaluate the dynamics of water ingestion in patients with achalasia and healthy volunteers; b) evaluate the effect of sex and age in water ingestion; c) evalu- ate the influence of the esophageal involvement by the disease on water ingestion; d) compare the results of idiopathic achalasia with achalasia caused by Chagas' disease.

\section{METHODS}

Seventy-nine patients ( 28 men; $35 \%$ ) with achalasia, 50 caused by Chagas' disease and 29 with idiopathic achalasia, aged from 23 to 79 years (mean: 52.7 years, SD: 14.2 years) and 91 healthy volunteers (44 men; 48\%) aged from 20 to 77 years (mean: 46.5 , SD: 15.7 years) were included in the study.

Patients had dysphagia for liquid and solid foods, with esophageal retention of barium sulfate inside the esophageal body showed by radiologic examination. Upper digestive endoscopy was performed in all patients to rule out complications of the disease or other causes of dysphagia. The degree of esophageal involvement was assessed by anteroposterior radiograph of esophagus obtained at a fixed distance of $1.8 \mathrm{~m}$ at 10 seconds after the swallowing of 200 $\mathrm{mL}$ of liquid barium sulfate. The result was considered normal if there was no barium remaining in the esophagus; grade I esophageal disease if there was esophageal retention of barium sulfate but the distal esophageal diameter was less than $4 \mathrm{~cm}$; or grade II if there was esophageal retention and the distal esophageal diameter was between 4 and $7 \mathrm{~cm}^{(12)}$. Epidemiology and serologic test for Chagas'

Declared conflict of interest of all authors: none

Disclosure of funding: no funding received

Departamentos de Clínica Médica e de Oftalmologia, Otorrinolaringologia e Cirurgia de Cabeça e Pescoço da Faculdade de Medicina de Ribeirão Preto da Universidade de São Paulo, Ribeirão Preto SP, Brasil

Corresponding author: Roberto Oliveira Dantas. Orcid: 0000-0003-2183-0815. E-mail: rodantas@fmrp.usp.br. 
disease was used to establish the diagnosis of idiopathic or Chagas' disease achalasia. Final diagnosis of achalasia was confirmed by manometric examination, performed with the method of water perfusion in all subjects with clinical and radiological suspect of achalasia. Aperistalsis in the esophageal body and impaired or absent relaxation of the lower esophageal sphincter were indicative of achalasia ${ }^{(1,8)}$. No patient had endocrine, neurologic or cardiologic diseases, and none of those with Chagas' disease had cardiac failure or cardiac arrhythmia ${ }^{(13)}$.

Control group was composed of healthy volunteers from the same community as the patients, recruited by advertisement in the hospital. They did not have dysphagia, regurgitation, heartburn; or other digestive symptoms, endocrine, neurologic, cardiologic diseases or other notable systemic disease. The investigation was approved by the Human Research Committee of the University Hospital. All controls and patients gave written informed consent to participate in the study and the anonymity of each participant was preserved.

Swallowing dynamics was assessed by the water-drinking test ${ }^{(10,11,14-16)}$. In the sitting position, individuals were asked to drink in a "confortable" way without interruption $50 \mathrm{~mL}$ of water at room temperature from a plastic cup. A stopwatch was started when the first drop of water touched the lip, and stopped when the larynx of the volunteers came to rest after the last swallow. The drinking test was performed in triplicate, with an interval of at least 30 seconds between measurements. The mean of the three tests of each individual was used for analysis. The researchers involved in this study had previous training in timing and counting the swallows, which was defined as the number of movements of the upper larynx. The following parameters were also calculated: (a) inter-swallow interval - the time required to complete the task, in seconds, divided by the number of swallows during the task; (b) swallowing rate - volume of water $(\mathrm{mL})$ divided by the time, in seconds; (c) volume in each swallow - volume drunk $(\mathrm{mL})$ divided by the number of swallows.

Participants were grouped by sex (men and women), age (younger: 20-49 years, older: 50-79 years), severity of the esophageal radiological findings (Grade I or Grade II), and by etiology of the disease (idiopathic or Chagas). Mean age was 33.4(7.7) years among younger and 61.1 (7.2) years among older subjects in the control group, and 38.3 (7.7) years and 63.1 (7.2) years among younger and older subjects, respectively, in the achalasia group.

Between-group comparisons were analyzed by covariance test (ANCOVA). Results are reported as mean and standard deviation (SD). All tests were two-tailed, and a $p$ value of $\leq 0.05$ was considered statistically significant.

\section{RESULTS}

Patients with achalasia had a longer time to ingest the water, a greater number of swallows, had a longer inter-swallows interval, a lower swallowing rate and a smaller volume per swallow (TABLE 1).

Women with achalasia had a longer inter-swallow interval and lower swallowing rate as compared with men with achalasia, whereas in control volunteers women had a shorter inter-swallow interval and a lower volume in each swallow than men (TABLE 2).

TABLE 1. Results of the water drinking test in patients with achalasia $(n=79)$ and controls $(n=91)$.

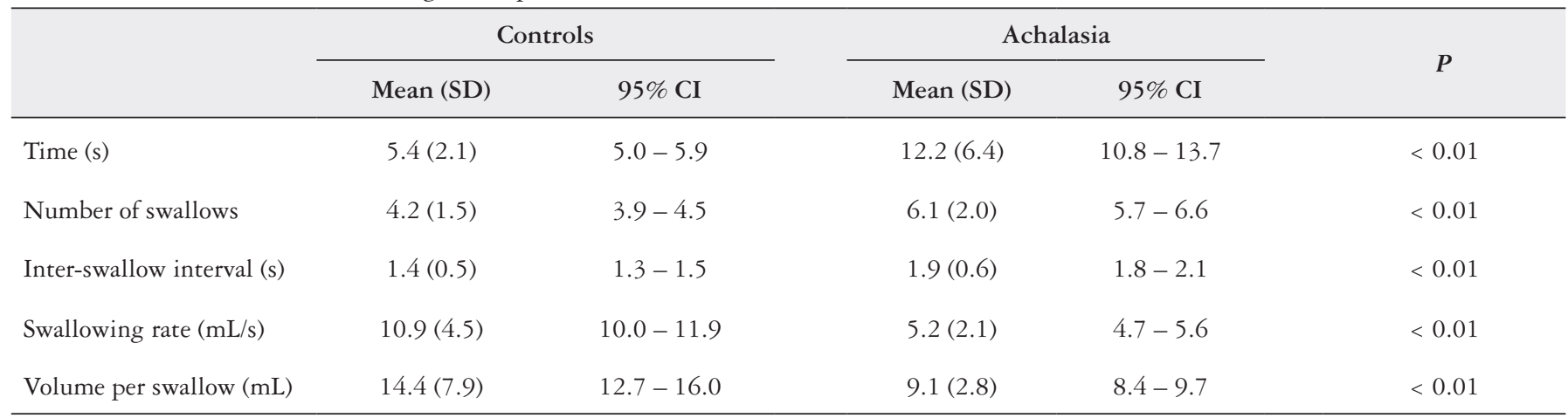

TABLE 2. Results of the water drinking test patients with achalasia $(n=79)$ and controls $(n=91)$, by sex.

\begin{tabular}{|c|c|c|c|c|c|c|}
\hline & \multicolumn{3}{|c|}{ Controls } & \multicolumn{3}{|c|}{ Achalasia } \\
\hline Number of swallows & $4.1(1.6)$ & $4.4(1.3)$ & 0.45 & $5.7(1.4)$ & $6.4(2.2)$ & 0.08 \\
\hline Swallowing rate $(\mathrm{mL} / \mathrm{s})$ & $11.2(4.9)$ & $10.7(4.0)$ & 0.61 & $5.7(1.8)$ & $4.9(2.2)$ & 0.03 \\
\hline Volume per swallow (mL) & $16.2(10.5)$ & $12.7(3.8)$ & 0.03 & $9.5(2.3)$ & $8.8(3.0)$ & 0.23 \\
\hline
\end{tabular}

Mean and (SD). 
We found no effect of age on swallowing parameters in our study groups (TABLE 3). However, considering the age subgroups, healthy individuals aged $60-79$ years $(n=23)$ had a significantly lower swallowing rate $(9.1 \mathrm{~mL} / \mathrm{s})$ than younger subjects $(\mathrm{n}=48$, $11.8 \mathrm{~mL} / \mathrm{s}, P=0.04)$, whereas in patients with achalasia $(\mathrm{n}=33)$ this difference was not observed $(4.8 \mathrm{~mL} / \mathrm{s}$ vs $5.4 \mathrm{~mL} / \mathrm{s}$, respectively, $P>0.05)$. With respect of the volume per swallow these oldest group has a volume of $12.6 \mathrm{~mL}$ among the healthy volunteers and $9.1 \mathrm{~mL}$ among the achalasia patients, without differences with the younger group (controls: $15.1 \mathrm{~mL}$, achalasia: $9.4 \mathrm{~mL}, P>0.05$ ).

There was no difference between grade I and grade II achalasia patients, or between patients with idiopathic achalasia and those with Chagas' disease in swallowing parameters $(P>0.30$, TABLE 4$)$.

\section{DISCUSSION}

As expected, water drinking test showed that patients with achalasia had difficulty in drinking $50 \mathrm{~mL}$ of water, probably due to altered esophageal motility and dysphagia.

Water ingestion in healthy individuals has shown to be different between men and women. Women have short interval between swallows, and lower number of swallows, swallowing rate and volume per swallows than men ${ }^{(11)}$. These findings were corroborated by our results, showing a shorter inter-swallows interval and a lower volume per swallows in healthy women than men. In addition, a more severe impairment of swallowing was found in women with achalasia than men, with a significant longer inter-swallow intervals and lower swallowing rate. However, the possibility that this difference may be caused by the influence of sex on swallowing behavior rather than by a more severe impairment of esophageal motility and transit than men cannot be ruled out. Also, differences in swallowing between men and women is a matter of controversy ${ }^{(17)}$, and may not be clinically relevant among patients with achalasia. In healthy subjects, gender does not seem to influence esophageal motility ${ }^{(18)}$.

Aging process has a clear influence on swallowing ${ }^{(19-23)}$. Swallowing capacity decreases as the individual gets older, with altered oral, pharyngeal and esophageal function ${ }^{(19)}$, manifested by prolongation of oral and pharyngeal phases ${ }^{(23)}$, esophageal motility abnormalities $^{(23)}$, and reduction in the cross-sectional area of the upper esophageal sphincter opening during swallows ${ }^{(19)}$. In patients with idiopathic achalasia without treatment, however, the frequency and severity of the symptoms are inversely correlated with age ${ }^{(24)}$, which means that older subjects have less symptoms than younger ones, indicating that these functional abnormalities are not aggravated by aging. This is also seen in patients with Chagas' disease, in whom aging is not associated with aggravation of esophageal dysfunction $^{(12)}$.

During the aging process, there is a loss of the esophageal myenteric plexus ${ }^{(25,26)}$, which explain the deterioration in esophageal motility and function in subjects with established esophageal motility disease ${ }^{(21)}$. This change, however, does not exacerbate esophageal dysfunction in achalasia, be it before or after treatment ${ }^{(24)}$ or in Chagas' disease ${ }^{(12)}$.

TABLE 3. Results of the water drinking test in younger (20-49 yeas) and older (50-79 years) patients with achalasia and control subjects.

\begin{tabular}{|c|c|c|c|c|c|c|}
\hline & \multicolumn{3}{|c|}{ Controls } & \multicolumn{3}{|c|}{ Achalasia } \\
\hline Number of swallows & $4.2(1.6)$ & $4.3(1.3)$ & 0.75 & $5.7(1.8)$ & $6.4(2.1)$ & 0.07 \\
\hline Swallowing rate $(\mathrm{mL} / \mathrm{s})$ & $11.8(4.9)$ & $10.0(3.8)$ & 0.07 & $5.4(2.0)$ & $5.0(2.1)$ & 0.27 \\
\hline Volume per swallow (mL) & $15.1(9.9)$ & $13.6(4.9)$ & 0.53 & $9.4(2.4)$ & $8.8(3.0)$ & 0.30 \\
\hline
\end{tabular}

Mean (SD).

TABLE 4. Results of the water-drinking test in patients with grades I and II idiopathic achalasia and achalasia caused by Chagas disease.

\begin{tabular}{|c|c|c|c|c|c|c|}
\hline & \multicolumn{3}{|c|}{ Idiopathic achalasia } & \multicolumn{3}{|c|}{ Chagas' disease } \\
\hline & Grade $I(n=15)$ & Grade II $(n=14)$ & Total $(n=29)$ & Grade $I(n=26)$ & Grade II $(n=24)$ & Total $(n=50)$ \\
\hline Number of swallows & $5.9(1.7)$ & $6.0(2.6)$ & $6.0(2.1)$ & $6.2(1.9)$ & $6.2(2.1)$ & $6.2(2.0)$ \\
\hline Swallowing rate $(\mathrm{mL} / \mathrm{s})$ & $4.9(2.1)$ & $5.4(2.6)$ & $5.2(2.4)$ & $5.5(2.1)$ & $5.1(1.8)$ & $5.3(2.0)$ \\
\hline Volume per swalow (mL) & $9.4(3.2)$ & $9.6(2.9)$ & $9.5(3.0)$ & $8.9(2.6)$ & $9.1(3.1)$ & $9.0(2.8)$ \\
\hline
\end{tabular}

Mean (SD). $P>0.30$ grade I vs grade II and Chagas' disease vs idiopathic achalasia. 
Although one may expect that patients with increased esophageal diameter have a more severe esophageal dysfunction than patients with normal esophageal diameter, we did not find differences in the drinking test results between these subgroups of patients. It is possible that, for water ingestion, the most important influencing factor on bolus transit is the absence of lower esophageal sphincter relaxation, which may not be different between grades I and II. In fact, this is, at least in part, the reason for therapeutic success of achalasia by pneumatic dilation or myotomy, which promotes a reduction in the gastroesophageal junction resistance to flow and improvement of symptoms in patients grades I and II. In addition, despite known differences between achalasia caused by Chagas' disease and idiopathic ${ }^{(27-29)}$, including altered pharyngeal transit ${ }^{(30,31)}$, our results did not show differences in the test between patients with these conditions.

The investigation has some limitations. Drinking test results may be affected by the subjects' behavior and perception of dysphagia. However, reflects what happens to patients during the everyday water ingestion. The different results between men and women with achalasia could be consequence of a more intense esophageal impairment by the disease in women, however grade II in esophageal radiologic examination were more frequent in men $(61 \%)$ than in women (43\%). Evaluation of ingestion of other consistency, as a paste bolus, should added more information to the investigation.

In conclusion, patients with achalasia has difficulty in drinking water. This investigation showed a gender but not an age effect on the results of water-drinking test. The aging process do not seems to cause further deterioration of this functional test. There was no difference in swallowing parameters between patients with idiopathic achalasia and patients with Chagas' disease, or difference between patients with increased esophageal diameter and patients with normal esophageal diameter.

\section{Authors' contribution}

Dantas RO, Cassiani RA, Santos CM and Alves LMT: participated in the design of the study, in collection, analysis and interpretation of data, in the writing of the manuscript and in making the decision to submit it for publication.

Dantas RO, Cassiani RA, Santos CM, Alves LMT. Dinâmica da ingestão de água em pacientes com acalasia: influência de sexo e idade. Arq Gastroenterol

RESUMO - Contexto - Acalásia é uma doença que causa dificuldade no transporte do bolo deglutido da boca ao estômago, consequente à ausência das contrações peristálticas no esôfago e relaxamento parcial ou ausente do esfíncter inferior do esôfago. Objetivo - O objetivo desta investigação foi: a) avaliar a dinâmica da ingestão de água em pacientes com acalásia, idiopática ou causada pela doença de Chagas; b) avaliar a influência do sexo e da idade na dinâmica da ingestão de água. Métodos - A investigação foi realizada em 79 pacientes com acalásia (27 idiopática e 52 Chagas) e 91 voluntários saudáveis, todos avaliados pelo teste de ingestão de água. Os indivíduos ingeriam, em triplicata e sem pausas, $50 \mathrm{~mL}$ de água, a ingestão era cronometrada e o número de deglutições contadas. Também foram medidos: (a) intervalo entre deglutições - tempo para completar a tarefa, dividido pelo número de deglutições durante a tarefa; (b) fluxo de deglutição - volume ingerido dividido pelo tempo de ingestão; (c) volume de cada deglutição - volume ingerido dividido pelo número de deglutições. Resultados - Os pacientes com acalásia levaram mais tempo (média 12,2 segundos) para ingerir todo o volume que voluntários sadios (5,4 segundos), e apresentaram maior número de deglutições, intervalo mais longo entre as deglutições, menor fluxo de deglutição $(5,2 \mathrm{~mL} / \mathrm{s}$ vs $10,9 \mathrm{~mL} / \mathrm{s}$, nos controles) e menor volume em cada deglutição ( $9,1 \mathrm{~mL}$ vs $14,4 \mathrm{~mL}$ nos controles). Entre os voluntários saudáveis, as mulheres tiveram um intervalo entre deglutições mais curto e menor volume em cada deglutição em comparação aos homens e, na acalásia, as mulheres tiveram um intervalo mais longo entre as deglutições e menor fluxo de ingestão. Não houve diferenças significativas entre indivíduos mais jovens e mais velhos, entre os voluntários saudáveis e entre os indivíduos com acalásia. Não houve diferenças entre pacientes com doença de Chagas e pacientes com acalasia idiopática, ou entre pacientes com aumento ou não no diâmetro esofágico. Conclusão - Pacientes com acalásia têm dificuldade em ingerir água, levando mais tempo para completar a tarefa, que é influenciada pelo sexo dos indivíduos, mas não pela idade ou dilatação do esôfago.

DESCRITORES - Transtornos de deglutição. Acalásia esofágica. Doença de Chagas. Esôfago. Deglutição. Doenças do esôfago. Junção esofagogástrica. 


\section{REFERENCES}

1. Pressman A, Behar J. Etiology and pathogenesis of idiopathic achalasia. J Clin Gastroenterol. 2017;51:195-202.

2. Ates F, Vaezi MF. The pathogenesis and management of achalasia: current status and future directions. Gut Liver. 2015;9:449-63.

3. Farrukh A, Mayberry JF. Achalasia: an epidemiologic update. Esophagus. 2015;12:170-4.

4. Pandolfino JE, Gawron AJ. Achalasia: a systematic review. JAMA. 2015;313:1841-52

5. Pandolfino JE, Kahrilas PJ. Presentation, diagnosis and management of achalasia. Clin Gastroenterol Hepatol. 2013;11:887-97.

6. Matsuda NM, Miller SM, Évora PRB. The chronic gastrointestinal manifestations of Chagas' disease. Clinics. 2009;64:1219-24.

7. Oliveira RB, Troncon LEA, Dantas RO, Meneghelli UG. Gastrointestinal manifestations of Chagas' disease. Am J Gastroenterol. 1998;93:884-9.

8. Vaezi MF, Felix VN, Penagini R, Mauro A, Moura EGH, Pu LZCT, Martinek J, Rieder E. Achalasia: from diagnosis to management. Ann N Y Acad Sci. 2016;1381:34-44.

9. Dantas RO, Alves LMT, Cassiani RA, Santos CM. Clinical measurement of swallowing and proximal esophageal contractions in Chagas' disease. Esophagus. 2009; 6:231-6.

10. Hughes TA, Wiles CM. Clinical measurement of swallowing in healthy and neurogenic dysphagia. Q J Med. 1996;89:109-16.

11. Alves LMT, Cassiani RA, Santos CM, Dantas RO. Gender effect on the clinical measurement of swallowing. Arq Gastroenterol. 2007;44:227-9.

12. Meneghelli UG, Peria FM, Darezzo FMR, Almeida FH, Rodrigues CM, Aprile $\mathrm{LRO}$, et al. Clinical, radiographic, and manometric evolution of esophageal involvement by Chagas' disease. Dysphagia 2005;20:40-5.

13. Rassi A Jr, Rassi A, Marin-Neto JA. Chagas' disease. Lancet 2010; 375:1388-402.

14. Belo LR, Gomes NAC, Coriolano MGWS, Souza ES, Moura DAA, Asano AG, et al. The relationship between limit of dysphagia and average volume per swallow in patients with Parkinson's disease. Dysphagia. 2014;29:419-24.

15. Chee C, Arshad S, Singh S, Mistry S, Hamdy S. The influence of chemical gustatory stimuli on oral anaesthesia on healthy human pharyngeal swallowing. Chem Senses. 2005;30:393-400.

16. Teismann IK, Steinstraeter O, Stoeckight K, Sontrup S, Wollbrink A, Pantev C, et al. Functional oropharyngeal sensory disruption interferes with the cortical control of swallowing. BMC Neuroscience. 2007;8:62-9.
17. Molfender SM, Steele CM. Variation in temporal measures of swallowing: sex and volume effects. Dysphagia. 2013; 28:226-33.

18. Costa TV, Dantas RO. Esophageal motility in men and women evaluated by high-resolution manometry. Arq Gastroenterol. 2017;54:145-7.

19. Wirth R, Dziewas R, Beck AM, Clavé P, Handy S, Heppner HJ, et al. Oropharyngeal dysphagia in older persons - from pathophysiology to adequate intervention: a review and summary of an international expert meeting. Clin Interv Aging. 2016;11:189-208.

20. Smukalla SM, Dimitrova I, Feintuch JM, Khan A. Dysphagia in the elderly. Curr Treat Options Gastro 2017; 15:382-96.

21. Shim YK, Kim N, Park YH, Lee JC, Sung J, Choi YJ, et al. Effects of age on esophageal motility: use of high-resolution esophageal impedance manometry. J Neurogastroenterol Motil. 2017;23:229-36.

22. Alvarenga EHL, Dall'Oglio GP, Murano EZ, Abrahão M. Continuum theory: presbyphagia to dysphagia? Functional assessment of swallowing in the elderly. Eur Arch Otorhinolaryngol. 2018;275:443-9.

23. Aslam M. Vaezi MF. Dysphagia in the elderly. Gastroenterol Hepatol. 2013;9:784-95

24. Downs DJ, Jadick G, Swaid F, Ross SB, Rosemurgy AS. Age and achalasia: how does age affect patients presentation, hospital course, and surgical outcomes? Am Surg 2017;83:952-61.

25. Köberle F. Chagas' disease and Chagas' syndromes: the pathology of American trypanosomiasis. Adv Parasitol. 1968;6:63-116.

26. Meciano Filho J, Caravalho VC, de Souza RR. Nerve cell loss in the mienteric plexus of the human esophagus in relation to age: a preliminary investigation. Gerontology. 1995;41:18-21.

27. Dantas RO, Deghaide NHS, Donadi EA. Esophageal motility of patients with Chagas' disease and idiopathic achalasia. Dig Dis Sci. 2001;46:1200-6.

28. Herbella FAM, Oliveira DRFC, Del Grande JC. Are idiopathic and chagasic achalasia two different diseases? Dig Dis Sci. 2004;49:353-60.

29. Dantas RO. Differences between idiopathic and chagasic achalasia. Mini-Invasive Surg. 2017:353-60.

30. Jones B, Donner MW, Rubesin SE, Ravich WJ, Hendrix TR. Pharyngeal findings in 21 patients with achalasia of the esophagus. Dysphagia. 1987;2:87-92.

31. Santos CM, Cassiani RA, Dantas RO. Videofluoroscopic evaluation of swallowing in Chagas' disease. Dysphagia. 2011;26:361-5. 